\title{
Regimes of the North Australian Wet Season
}

\author{
MiCK POPE \\ Bureau of Meteorology Training Centre, Bureau of Meteorology, Melbourne, Victoria, Australia \\ CHRISTIAN JAKOB AND MiCHAEL J. REEDER \\ School of Mathematical Sciences, Monash University, Melbourne, Victoria, Australia
}

(Manuscript received 27 January 2009, in final form 28 July 2009)

\begin{abstract}
The variability of the north Australian wet season is examined by performing cluster analysis on the wind and thermodynamic information contained in the 2300 UTC radiosonde data at Darwin for 49 wet seasons (September-April) from $1957 / 58$ to 2005/06. Five objectively derived regimes of the wet season are obtained and are found to differ significantly in their synoptic environment, cloud patterns, and rainfall distributions. One regime is primarily associated with the trade wind regime. Two regimes are associated with the lead up to and break periods of the monsoon at Darwin. A fourth regime is clearly identified with the active monsoon at Darwin and is offered as a definition of monsoon onset. This regime captures the active monsoon environment associated with significant widespread rainfall. The fifth regime is a mixed regime, with some days associated with the inactive monsoon, a period of westerly zonal winds at Darwin associated with relatively suppressed convection compared with the active monsoon. Other days for this regime are break period conditions with a low-level westerly flow below $900 \mathrm{hPa}$.
\end{abstract}

\section{Introduction}

Rainfall in the tropics is highly seasonal. Away from the equator, the rain falls mainly in the summer half of the year, which is commonly called the wet season (Webster et al. 1998). For example, over northern Australia (Fig. 1), the geographical focus of the present study, more than $90 \%$ of the rain falls between November and April (Nicholls et al. 1982).

This annual cycle of precipitation in the tropics shows a great deal of higher-frequency variability associated the passage of individual synoptic-scale disturbances, the Madden-Julian oscillation, and, most importantly, the onset and vacillation of the (summer) monsoon. Although the details vary considerably from region to region, the defining feature of all monsoon circulations is an annual reversal in the wind from dry, wintertime easterlies to moist, summertime westerlies (Ramage 1971). While the monsoon is accompanied by periods of heavy, wide-

Corresponding author address: Mick Pope, GPO Box 1289, Bureau of Meteorology Training Centre, Bureau of Meteorology, Melbourne, VIC 3001, Australia.

E-mail:m.pope@bom.gov.au spread precipitation, a significant proportion of the rain falls during the transitional periods before and after the monsoon (Cook and Heerdegen 2001; Marteau et al. 2009). For example, up to $30 \%$ of the annual precipitation over northern Australia falls during the premonsoonal period (Nicholls 1984).

The monsoon itself is highly variable also, vacillating between active and break phases. For example, during the northern Australian wet season, as the rising branch of the Hadley circulation migrates southward, the broadscale winds in the lower half of the troposphere reverse from deep easterlies to deep westerlies. This change heralds the active phase of the monsoon and the associated heavy, widespread precipitation (Drosdowsky 1996, hereafter D96). Conversely, the break phase is accompanied by lower-level easterlies. Isolated, deep convection regularly forms on the sea breeze front during the break phases over northern Australia (Keenan and Carbone 1992). The principal aim of the work presented here is to characterize the main modes of variability by identifying objectively the broadscale weather regimes that make up the Australian wet season.

One of the important characteristics of the wet season is the date of the monsoon onset, and there are numerous 


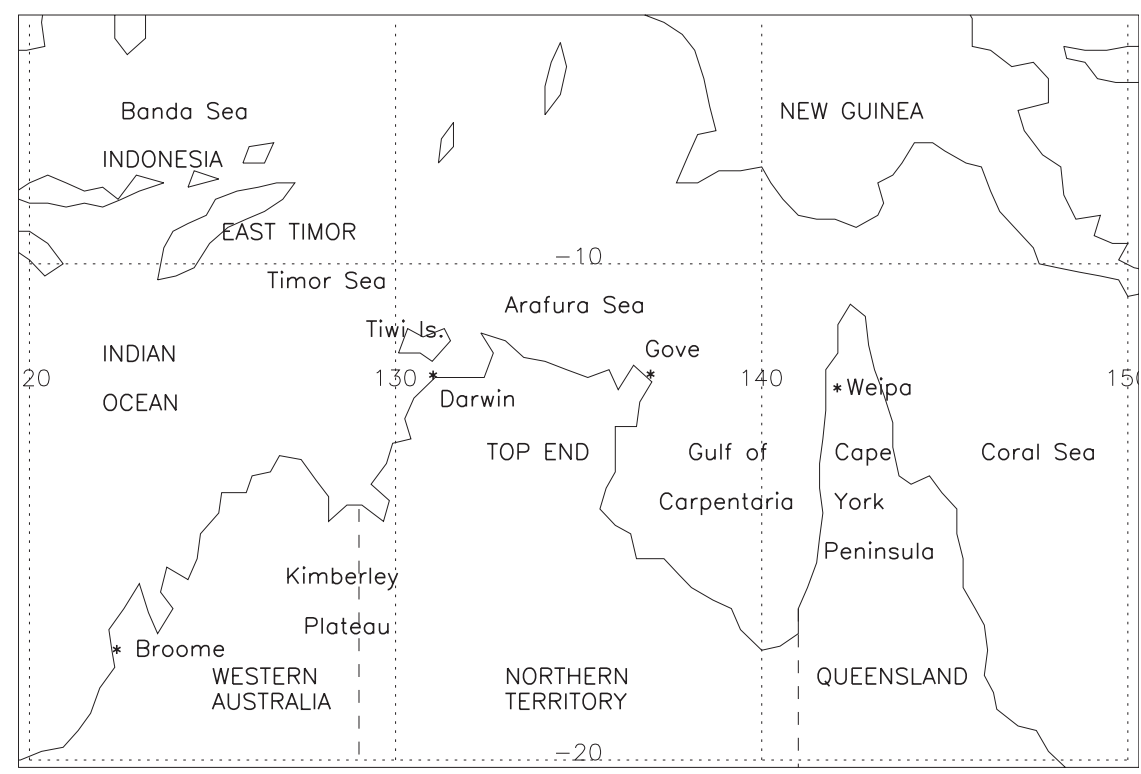

FIG. 1. Map of tropical northern Australia and surrounding waters, showing the location of Darwin.

ways to define this date. For northern Australia these include the first occurrence of wet, westerly, zonal winds at Darwin (Troup 1961; Hendon and Liebmann 1990); the arrival of deep-layer mean westerly winds to $500 \mathrm{hPa}$ with easterly winds above $300 \mathrm{hPa}$ at Darwin (D96); changes to the area-averaged $850-\mathrm{hPa}$ zonal winds and outgoing longwave radiation (Hung and Yanai 2004); the onset of widespread convection (Davidson et al. 1983); precipitable water (Zeng and Lu 2004); the date when a certain fraction of the seasonal rain has fallen (Smith et al. 2008); or the reaching of some arbitrary threshold (Nicholls et al. 1982; Jackson 1986, 1988; Cook and Heerdegen 2001; Lo et al. 2007). A secondary aim of the study is to determine whether the objectively derived weather regimes can be used to identify the onset of the monsoon.

In this paper the variability of the north Australian wet season is examined using cluster analysis. The main data used in the analysis are wind and thermodynamic observations from the 2300 UTC radiosonde ascents at Darwin for 49 wet seasons (September-April) from $1957 / 58$ to $2005 / 06$. These data and the clustering algorithm are described in detail in section 2 . The resulting climatology of the wet season regimes is discussed in section 3. One of the regimes identifies the active monsoon at Darwin and provides the basis for defining the onset of the monsoon there. The seasonal and intraseasonal variability of each regime are discussed also. Section 4 examines the relationship between the active and inactive monsoon at Darwin and the wet season regimes. The physical significance of the wet season re- gimes are discussed in section 4 , and the main points summarized in section 5 .

\section{Objective wet season regimes}

\section{a. Data and method}

The dataset used in this study consists of the 2300 UTC radiosonde data from Darwin (Fig. 1) for the months from September to April for the austral summers from $1957 / 58$ to 2005/06, excluding 1992/93 owing to problems with the Australian Bureau of Meteorology's database. The 2300 UTC datais used to avoid modification of the environment by strong diurnal convection. Data are accepted for inclusion in the analysis where the temperature $(T)$, zonal wind $(U)$, and meridional wind $(V)$ data are available at the following levels: surface (assumed here to be $1013 \mathrm{hPa}$ ), 950, 925, 900, 850, 800, 750, 700, $650,600,550,500,400,300,200$, and $100 \mathrm{hPa}$ (a total of 16 levels). There were two changes in radiosonde instrumentation during the study period, with changes in the sensitivity of the humidity sensor of the radiosonde affecting the minimum recordable dewpoint temperatures $\left(T_{d}\right)$ to $-35^{\circ} \mathrm{C}$ before 1982 and $-50^{\circ} \mathrm{C}$ between 1982 and 1992. To avoid a possible moist bias due to the rejection of flights where a dry air mass results in $T_{d}$ values falling below the minimum recordable value at the required pressure levels, $T_{d}$ values are selected only to $500 \mathrm{hPa}$ (12 levels). The disparity in the number of levels does not affect the analysis as midtropospheric moisture exercises a strong influence over the results (see section $2 b$ ). Further quality control is applied to the 
data by rejecting records where any of the following criteria were met: $T_{d}<-110^{\circ} \mathrm{C},|U|$ or $|V|>75 \mathrm{~m} \mathrm{~s}^{-1}$ at any level or $T_{\text {surface }}<0^{\circ} \mathrm{C}$. Approximately $35 \%$ of the data is excluded during the quality control process, but is reincluded in later analysis.

To examine the variability of the wet season at Darwin, the temperature and wind data described above are sorted into regimes using cluster analysis. Cluster analysis is a technique used to compress large amounts of data by identifying the centers of natural clusters in the dataset, and has been used in a variety of meteorological applications (e.g., Gong and Richman 1995; Jakob and Tselioudis 2003; Arnott et al. 2004; Rossow et al. 2005; Pope et al. 2009). The algorithm used in the present study is the $K$-means cluster analysis algorithm (Afifi et al. 2004). The $K$-means algorithm provides $K$ clusters for any value of $K$ supplied, regardless of the physical significance of the results obtained. Objective techniques exist to constrain the choice of $K$ (e.g., Pope et al. 2009). However, for this study five clusters were chosen to correspond to five physically sensible wet season regimes. To focus on the most significant variability, it is imposed here that no more than one regime accounts for less than $10 \%$ of the data. Extending the analysis to more than five clusters, results in two or more clusters accounting for less than $10 \%$ of all days, with the new clusters further subdividing the dry southeasterly regimes.

After the clustering, the data excluded during quality control is reincluded in the analysis to provide a continuous dataset of wet season regimes. Of the $35 \%$ of missing data, $92 \%$ is matched directly with one of the regimes obtained with cluster analysis. The remaining $8 \%$ is assigned to the previous day's regime. This gap filling is largely done for gaps of one to two days. The missing data are distributed more or less evenly over all five regimes in proportion to their occurrence and do not represent data from one particular period with the exception of the 1992/93 season, which has been excluded from the analysis.

The other datasets used in this study are the 40-yr European Centre for Medium-Range Weather Forecasts Re-Analysis (ERA-40) (Uppala et al. 2005), the National Centers for Environmental Protection outward longwave radiation (OLR) dataset (Liebmann and Smith 1996), the Wheeler and Hendon (2004) real-time multivariate Madden-Julian oscillation (MJO) index, the Bureau of Meteorology rain gauge data, and the rainfall data from the Global Precipitation Climatology Project (GPCP; Adler et al. 2003).

\section{b. Wet season regimes}

The mean wind and thermodynamic profiles of the five wet season regimes at Darwin are shown in Fig. 2. The wind profile is shown as the $U$ and $V$ components by the solid and dashed lines, respectively; positive values are westerly and southerly winds, and negative values are easterly and northerly winds, respectively. The temperature and dewpoint temperature profiles are plotted on a skew $T-\log p$ diagram.

Regime 1 accounts for $9.3 \%$ of all cases and exhibits southeasterly winds below about $400 \mathrm{hPa}$ (approximately $7600 \mathrm{~m}$ ), with a maximum in wind speed near $800 \mathrm{hPa}(2000 \mathrm{~m})$. The moisture profile is very dry throughout the entire surface to the $500-\mathrm{hPa}(5900 \mathrm{~m})$ layer, with the dewpoint temperature rapidly decreasing with height. The surface dewpoint is lower than that for any of the other regimes. This regime is referred to as the dry east regime.

Regime 2 accounts for $10.6 \%$ of all cases. The zonal wind profile is westerly to approximately $400 \mathrm{hPa}$ (approximately $7000 \mathrm{~m}$ ) with zonal easterly winds above this level. The meridional wind profile is northerly, changing to southerly above $300 \mathrm{hPa}$. Regime 2 has the strongest upper-tropospheric zonal winds of all regimes. The temperature profile exhibits a small dewpoint depression, indicative of a moist atmosphere. This regime is referred to as the deep west regime and is identified with the active monsoon at Darwin. The deep west wind profile is consistent with the large-scale reversal of the global circulation associated with the migration of the monsoon trough (Fein and Stephens 1987). The deep west wind profile also satisfies the wind-based definition of monsoon onset of D96, consisting of zonal westerly winds to at least $500 \mathrm{hPa}$ with zonal easterly winds above $300 \mathrm{hPa}$.

Regime 3 accounts for $26.7 \%$ of all cases and shows a similar wind profile to that of the dry east regime, with low-level southeasterly winds and upper-level westerly winds. The change in wind direction occurs at a lower level than for the dry east regime, at about $550 \mathrm{hPa}$ $(4900 \mathrm{~m})$. The maximum wind speed for regime 3 occurs slightly higher, near $750 \mathrm{hPa}(2500 \mathrm{~m})$. The dewpoint temperatures in the 900-500-hPa layer are significantly higher than for the dry east regime. This regime is referred to as the east regime.

Regime 4 accounts for $16.5 \%$ of the data and exhibits a shallow westerly wind below about $800 \mathrm{hPa}(2000 \mathrm{~m})$ with weak easterly winds to $300 \mathrm{hPa}$, which steadily increase in strength above that level. The meridional winds for regime 4 are southerly throughout the depth of the atmosphere. The moisture profile for regime 4 shows a larger dewpoint depression than for the deep west regime, but has larger dewpoint temperatures than either the east or dry east regimes. This regime is referred to as the shallow west regime.

Regime 5 accounts for $36.7 \%$ of the data. The lowertropospheric zonal flow is easterly winds extending 

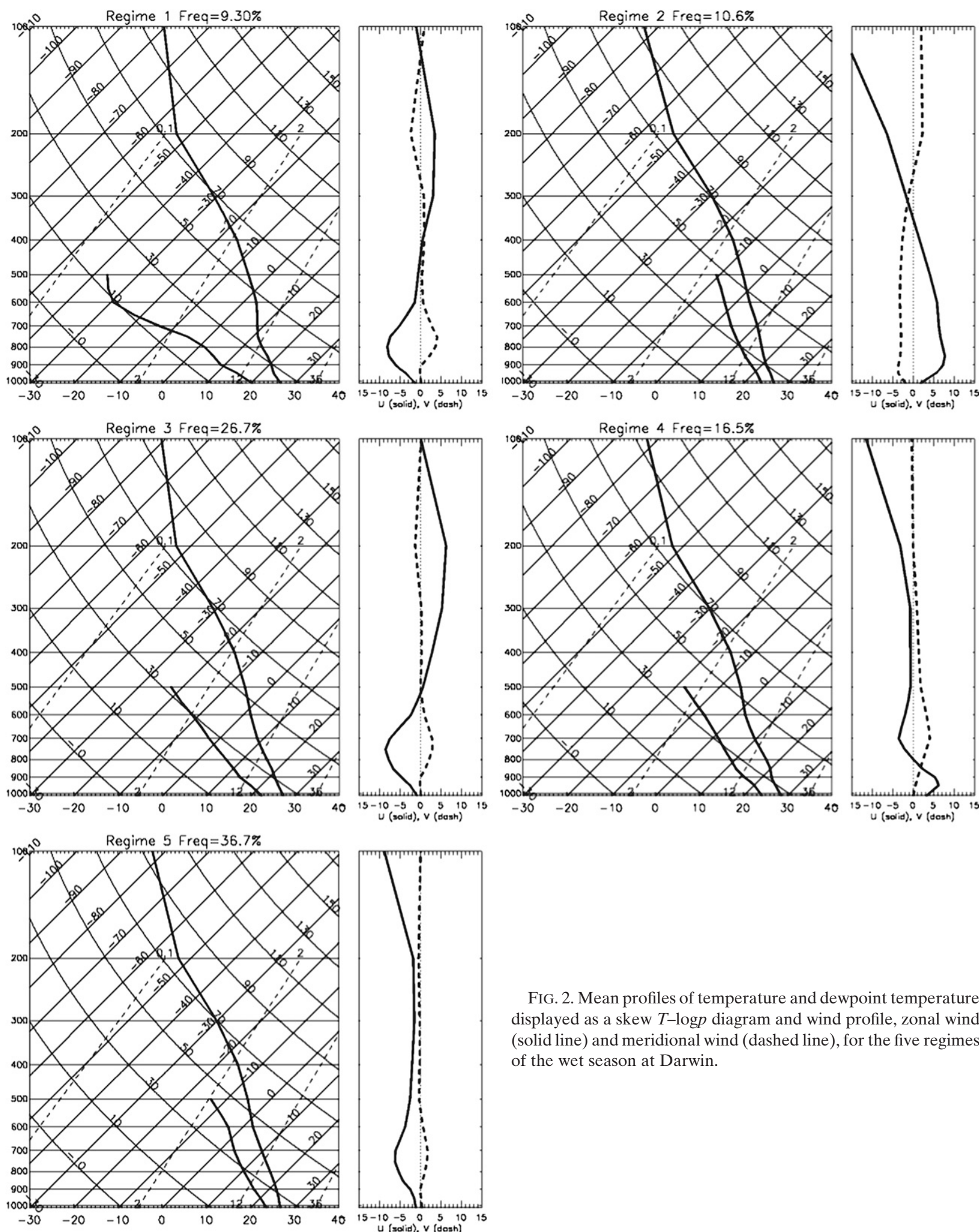

FIG. 2. Mean profiles of temperature and dewpoint temperature displayed as a skew $T-\log p$ diagram and wind profile, zonal wind (solid line) and meridional wind (dashed line), for the five regimes of the wet season at Darwin. 

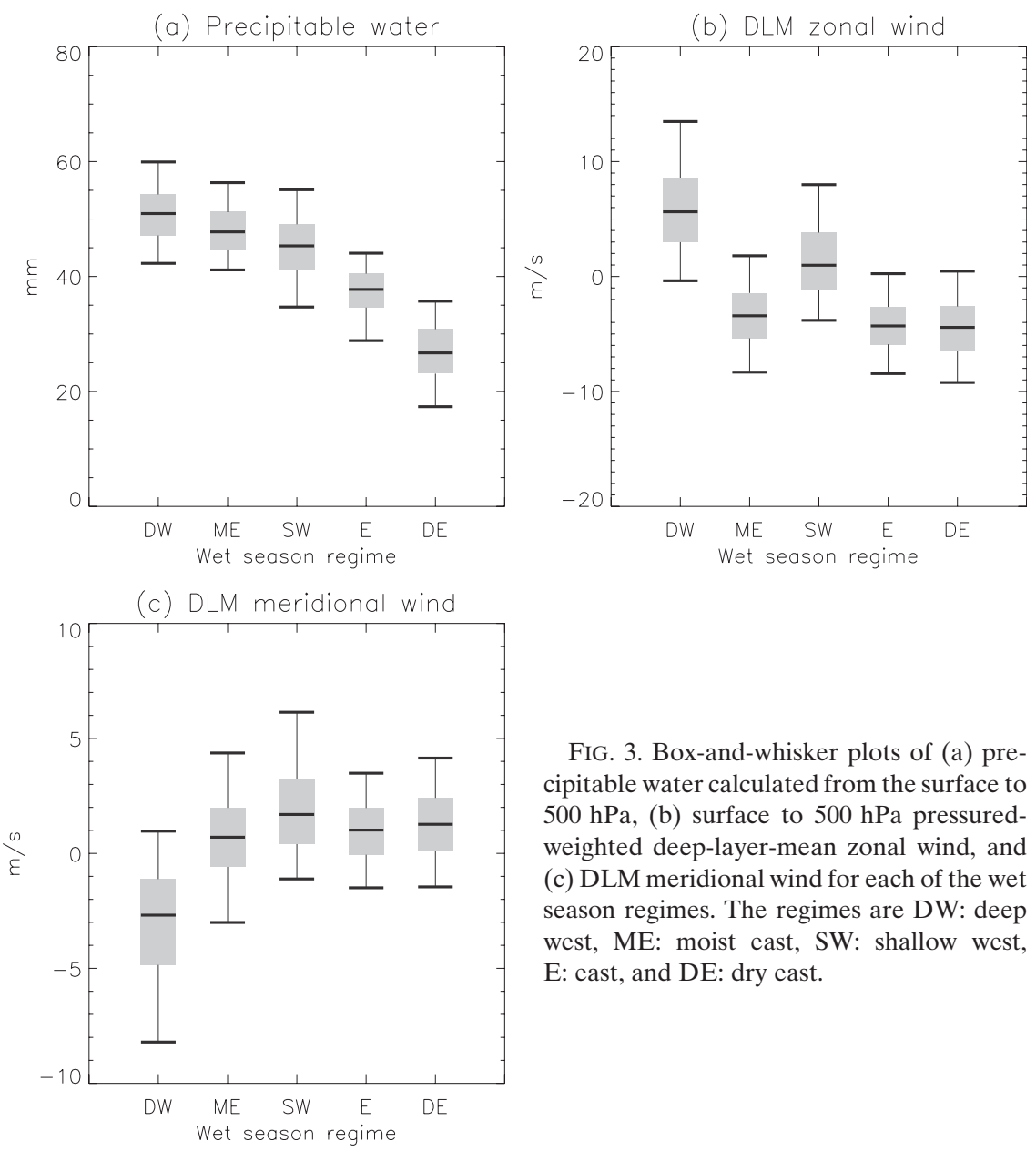

FIG. 3. Box-and-whisker plots of (a) precipitable water calculated from the surface to $500 \mathrm{hPa}$, (b) surface to $500 \mathrm{hPa}$ pressuredweighted deep-layer-mean zonal wind, and (c) DLM meridional wind for each of the wet season regimes. The regimes are DW: deep west, ME: moist east, SW: shallow west, E: east, and DE: dry east.

throughout the entire troposphere, but is weaker than either the east or dry east regimes. The meridional winds for regime 5 are also very light. Regime 5 also has a smaller dewpoint depression than the other easterly regimes. This regime is referred to as the moist east regime.

To examine the variability within each of the five regimes, box- whisker plots of pressure-weighted deep layer mean (DLM) zonal and meridional winds and precipitable water calculated for the surface to the $500-\mathrm{hPa}$ layer are shown in Fig. 3. Each box represents the 25 and 75 percentiles; the horizontal line is the median value and the whiskers are the 5 and 95 percentiles of DLM winds and precipitable water. The deep west (DW) regime has the largest values of precipitable water, with $90 \%$ of all cases in the $40-60-\mathrm{mm}$ range. At least $75 \%$ of all deep west regime days at Darwin have northerly meridional DLM winds and about $95 \%$ have westerly zonal DLM winds. The small numbers of cases where the DLM zonal winds are easterly indicate that the edges of regimes derived using cluster analysis are fuzzy because the parameters of the environment form a con- tinuum. The significance of these outliers will be discussed in section 4.

The shallow west (SW) regime has the third highest values of precipitable water of the five wet season regimes. At least $50 \%$ of the shallow west cases represent a zonal wind profile meeting the requirement of D96 for a zonal westerly DLM wind profile. However, the shallow west regime exhibits a southerly meridional DLM compared to the northerly meridional DLM of the deep west regime. The differences between the deep west and shallow west regimes are explained in terms of the broadscale synoptic environment in section 3 .

The three east regimes have similar DLM zonal wind distributions, with a mean value from -3 to $-4 \mathrm{~m} \mathrm{~s}^{-1}$ and a range from -9 to $+2 \mathrm{~m} \mathrm{~s}^{-1}$. The dry east (DE) and east (E) regimes have similar meridional DLM wind distributions with about $75 \%$ of all cases being southerly. The moist east (ME) regime has a much larger proportion of cases with northerly meridional winds. Differences between the east regimes are most obvious in the precipitable water values, with the dry east regime 


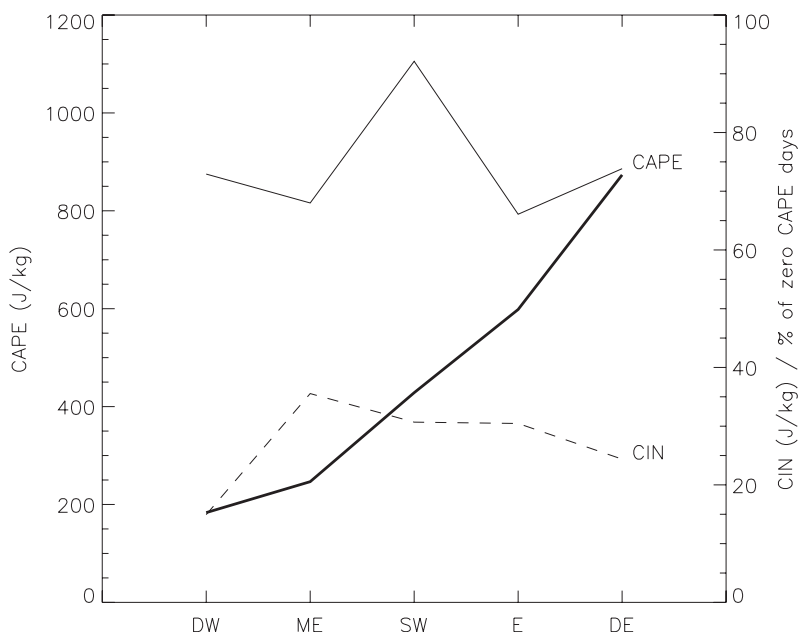

FIG. 4. Mean CAPE and CIN for nonzero CAPE days and the number of zero CAPE days (thick line) as a percentage of the total number of days for the five wet season regimes as in Fig. 3.

having the lowest values and moist east having the largest values. The differences in wind direction at Darwin are small, but result in large differences in the moisture profile (Fig. 2) and the precipitable water (Fig. 3), possibly reflecting differences in the large-scale circulation and hence moisture advection. The synoptic patterns associated with each of the wet season regimes will be examined below.

The temperature information is retained despite the small differences in the mean temperature profiles of the five regimes. Examination of the range of values for each regime (not shown) shows some significant differences in some cases, with low-level inversions present during the dry east regime.

Differences in surface moisture and temperature profiles affect the values of convective available potential energy (CAPE) and convective inhibition (CIN). The strength of convective updrafts is related to the value of CAPE. Large CIN and small CAPE is typically associated with the early and late seasons when surface moisture values are lower. Active monsoon periods are typically associated with low values of CAPE and weak convective updrafts with widespread stratiform rain, whereas the break monsoon periods are associated with large values of CAPE, strong updrafts, and isolated heavy convective precipitation (McBride and Frank 1999). Figure 4 shows the mean values of CAPE and CIN for days where CAPE was nonzero. The averages of CAPE and CIN were calculated using the maximum value of CAPE for parcels lifted from $850 \mathrm{hPa}$ or below. The value of CIN is undefined for days when there is no CAPE. Also shown is the number of days of zero CAPE as a percentage of the total number of days when each of

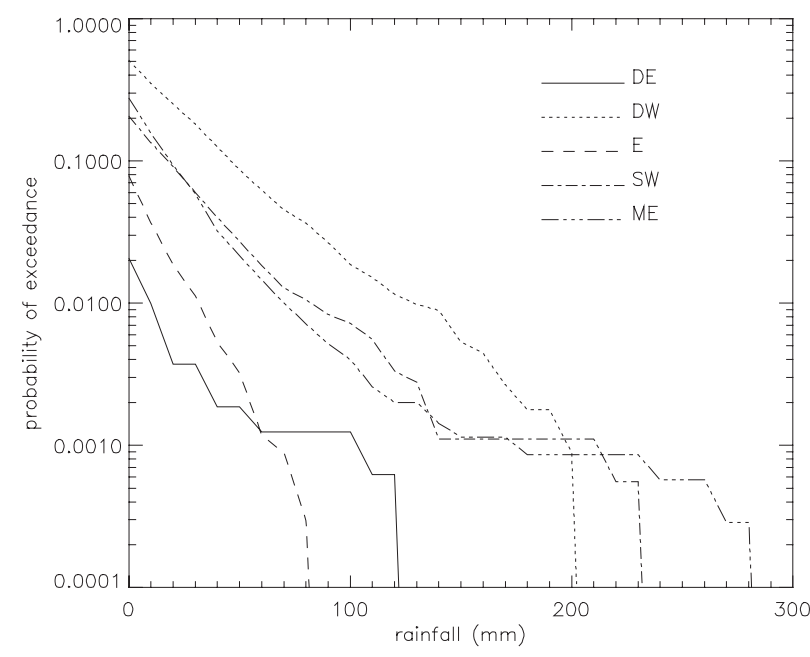

FIG. 5. Probability of exceedance of Darwin International Airport rain gauge 24-h rainfall total for the five wet season regimes as in Fig. 3. Rainfall is binned every $10 \mathrm{~mm}$.

the five wet season regimes is observed. The dry east regime has the largest percentage of zero CAPE days (greater than $90 \%$ ), consistent with the low surface dewpoint temperatures (Fig. 2a) and precipitable water (Fig. 3a). The association of the dry east regime with the lowest values of low-level dewpoint would imply that this regime should be associated with the largest values of CIN. However, the large number of zero CAPE days for this regime means that the CIN values are biased toward the few days when convective inhibition was smaller than average for this regime. Likewise, the mean CAPE for the dry east regime is relatively high compared to the other regimes because it is calculated for the few days when CAPE exists.

The deep west regime has the smallest percentage of zero CAPE days (about 15\%) and the smallest mean CIN (about $15 \mathrm{~J} \mathrm{~kg}^{-1}$ ). The mean CAPE values are comparable to all regimes but the shallow west regime. The east regime has the second highest number of zero CAPE days and the lowest mean CAPE of all monsoon regimes, with a mean CIN of about $30 \mathrm{~J} \mathrm{~kg}^{-1}$. The largest mean CAPE values are associated with the shallow west regime, about $1100 \mathrm{~J} \mathrm{~kg}^{-1}$. The moist east regime has the largest mean CIN (about $35 \mathrm{~J} \mathrm{~kg}^{-1}$ ) but the second lowest percentage of zero CAPE days.

Given that the main rainfall production mechanism in the tropics is deep convection, the differences in precipitable water, CAPE, and CIN among the five wet season regimes should be reflected in differences in rainfall statistics for Darwin. The 24-h rainfall total from the Darwin Airport rain gauge is shown in Fig. 5 as the probability of exceeding a given rainfall amount for the entire study period. Similar results are obtained if 


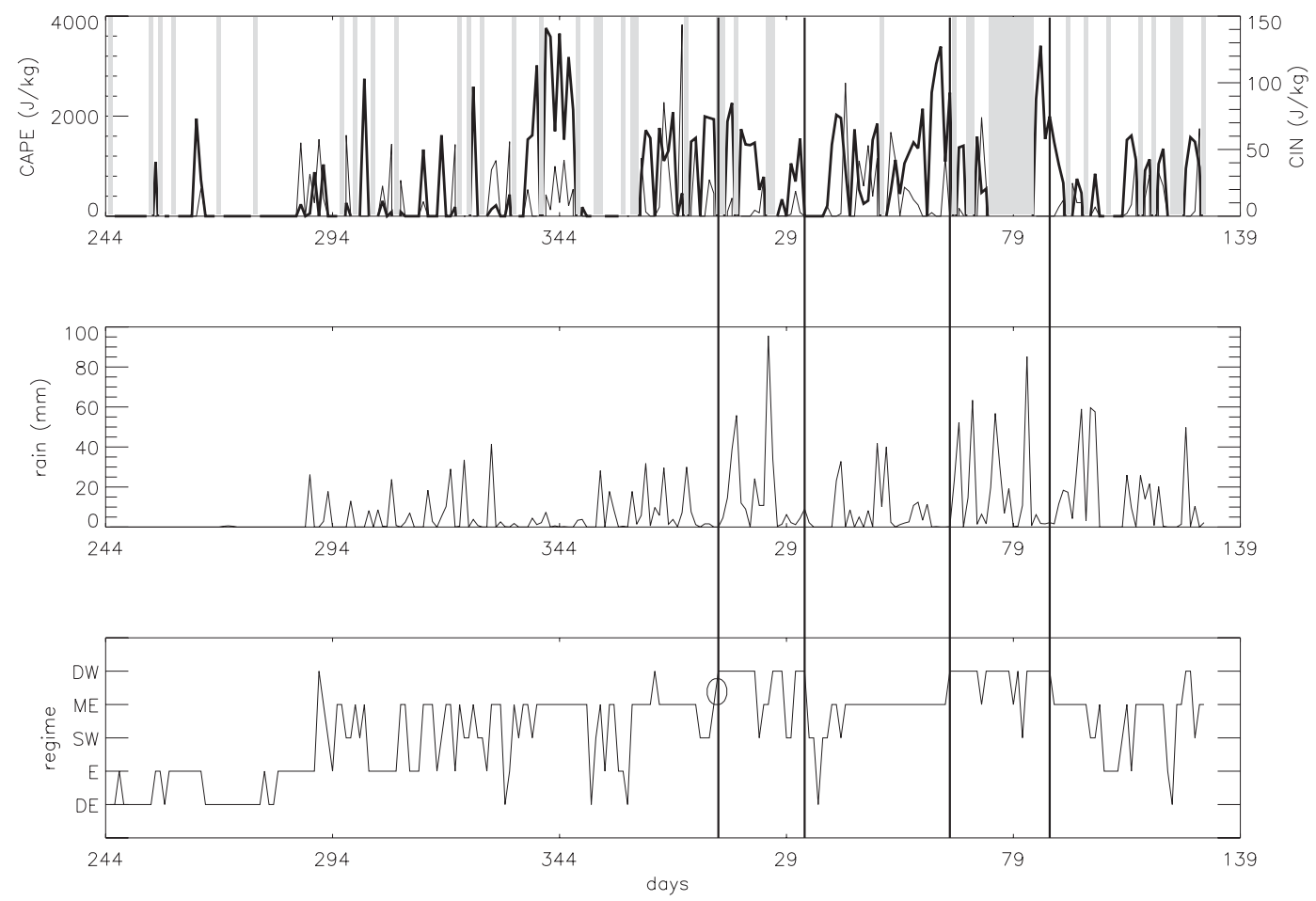

FIG. 6. Time series (Julian days) for the 2005/06 season (1 Sep-30 Apr) of (top) CAPE (thick line) and CIN (thin line), (middle) Darwin 24-h rainfall, and (bottom) the wet season regime. Days where CAPE was not calculated are indicated (gray bars). The vertical bars indicate the active monsoon periods. The $\mathrm{O}$ indicates the onset date following D96.

a multistation average is used (not shown), with smaller total valuesowing to averaging over the stations.

The dry east regime has the smallest rainfall totals, with the smallest probability (about $2 \%$ ) of exceeding $0 \mathrm{~mm}$ and very few events exceeding $100 \mathrm{~mm}$. The east regime has a larger probability of exceeding $0 \mathrm{~mm}$ than the dry east regime ( $8 \%)$, but it is extremely unlikely to ever exceed $100 \mathrm{~mm}$. The low probabilities for significant rainfall at Darwin for the east and dry east regimes are consistent with their low values of precipitable water. Further, the mean thermodynamic profile of the dry east regime (Fig. 2) hints at a low-level inversion (which is more apparent in individual soudings, not shown), which acts to limit the depth of convection. The deep west regime is most likely to be associated with nonzero rainfall totals (about $50 \%$ of days) due to the widespread rainfall typically observed with the active monsoon (e.g., May et al. 2008). The largest rainfall totals are associated with the moist east regime. The moist east regime exhibits deep easterly DLM winds, large values of precipitable water, and large rainfall, and is therefore consistent with a break monsoon environment. During break monsoon conditions, large values of CAPE are observed (McBride and Frank 1999), resulting in strong updrafts in isolated pulse convection and propagating squall lines (Keenan and Carbone 1992). Break period convection can produce significant rainfall totals (D96). Large rainfall events are also associated with the shallow west regime. However, compared to the deep west regime, the shallow west regime has a much lower probability of producing rainfall totals above $200 \mathrm{~mm}$.

Figure 6 shows a time series of CAPE, CIN, 24-h rainfall (at the Darwin airport), and wet season regime for the 2005/06 season. Approximately the first 50 days are dominated by the dry east and east regime. Values of CAPE are typically small during this time. The deep west regime is first observed on Julian day 287 (14 October). It is likely that this and the event on day 363 (29 December) do not represent a large-scale reversal of the global circulation associated with monsoon onset. The wind profiles for both days are clearly associated with a monsoon break (not shown). The event on day 363 occurs during a prolonged burst of the moist east regime and has been identified with the deep west regime by the clustering algorithm owing to the deep moisture profile. Likewise, days 116-117 are moist break environments.

The two events indicated by the horizontal bars are monsoon events at Darwin (days 13-32 and 64-86). The $\mathrm{O}$ indicates the onset according to D96, and is in agreement with the deep west onset. The values of CAPE 
during these periods tend to be smaller than for the moist east periods, for example, the moist east period centered on day 344, consistent with the results of McBride and Frank (1999). Likewise, some of the largest rainfall totals occur during the active periods. The time series shows that the deep west regime captures the heavy rainfall events associated with the active monsoon during the middle of the wet season, but can produce false alarms early and late in the season.

The false alarms are due to the fuzzy nature of the clusters produced by cluster analysis. Less than $0.5 \%$ of deep west days were identified during September and October. The monsoon is never observed this early, and deep west events during these months are associated with midlatitude troughs. However, November monsoon onset has been observed. Of the days identified as deep west during November in the entire data record, 10 days were identified with midlatitude troughs and two events with early monsoon onset using ERA-40 (not shown). The first event (22-25 November 1973) was associated with Tropical Cyclone Innes (D96) and the second with a westerly wind burst in the Timor Sea (29-30 November 1981; Hung and Yanai 2004) during an active phase of the MJO (Wheeler and Hendon 2004). Hence, the identification of wet season regimes could be improved by requiring the regime be matched for longer than a day.

\section{Climatology of wet season regimes}

The five objectively defined regimes of the wet season at Darwin represents information at a single location. It is unclear how representative these results are for the larger-scale state of the atmosphere. To shed more light on these issues this section examines the broadscale synoptic environment under which these five regimes occur to examine the relationship between point measurements and the synoptic environment.

\section{a. Synoptic environment}

To examine differences in the synoptic environment of the different Darwin wet season regimes, Fig. 7 shows mean sea level pressure (MSLP) anomalies and 10-m wind anomalies from the ERA-40 (Uppala et al. 2005) for each of the regimes. Also shown are the SeptemberApril mean 10-m winds and MSLP. The anomalies are with respect to the monthly means to remove the effects of the seasonal cycle. Pressure anomalies are shown every $0.5 \mathrm{hPa}$ and wind anomalies every $0.5 \mathrm{~m} \mathrm{~s}^{-1}$. The mean pattern for September-April (Fig. 7f) shows a heat low located over continental northwest Australia, with a trough extending down the west coast. A weaker inland trough is found over eastern Australia. Southeasterly trade winds occur over the Indian Ocean and
Coral Sea, with light winds equatorward of $5^{\circ} \mathrm{S}$. The monsoon trough is not evident in the September-April mean pattern owing to the predominance of the trade winds over the period.

The dry east regime (Fig. 7a) is associated with a weak high pressure anomaly over continental Australia. Weak southerly wind anomalies of less than $0.5 \mathrm{~m} \mathrm{~s}^{-1}$ are located in the Coral Sea and over eastern Australia and extend north of Australia over the Maritime Continent. The east regime (Fig. 7c) is associated with southeasterly wind anomalies in the Coral Sea and east to southeasterly wind anomalies over the Maritime Continent, reaching over $1 \mathrm{~m} \mathrm{~s}^{-1}$ over the Arafura Sea. The wind anomalies are much weaker over continental Australia for the east regime compared to the dry east regime. The positive pressure anomalies for the east regime are limited to eastern Australia, compared to the large-scale positive anomalies of the dry east regime. The moist east regime (Fig. 7e) has weak pressure anomalies over the entire region (less than $0.5 \mathrm{hPa}$ ) and weak wind anomalies over most of the region, exceeding $0.5 \mathrm{~m} \mathrm{~s}^{-1}$ over northern Australia. The differences in the large-scale wind anomalies in Fig. 7 explains the differences in the mean precipitable water values for each of the easterly zonal wind regimes shown in Fig. 3. The dry east regime has the lowest observed values of precipitable water due to the dry continental air mass being advected over Darwin by the southerly wind anomalies. The wind anomalies for the east regime are southeasterly over the Coral Sea, suggesting a moister maritime airmass than the dry east regime. The trough in the wind field anomalies for the moist east regime suggests an equatorial origin of the air mass over Darwin, consistent with the large values of precipitable water.

The deep west regime (Fig. 7b) is associated with strong west to northwesterly wind anomalies of over $3 \mathrm{~m} \mathrm{~s}^{-1}$ over northern Australia and negative pressure anomalies over continental Australia and surrounding waters. A cyclonic low pressure anomaly is located over northwestern Australia, with a trough in the wind field in the Coral and Solomon Seas. The equatorial origin of the air mass is consistent with the large values of precipitable water observed for the deep west regime (Fig. 3). The anomalous wind field shows a large region of convergence over Darwin and much of northern Australia. Convergence on the synoptic scale is a typical feature of the active monsoon (Davidson et al. 1983) and is responsible for widespread rainfall, consistent with the high probability of nonzero rainfall at Darwin (Fig. 5).

The shallow west regime is associated with negative pressure anomalies over the eastern half of continental Australia, together with zonal westerly wind anomalies of over $3 \mathrm{~m} \mathrm{~s}^{-1}$ over the Arafura Sea. Northwesterly wind 

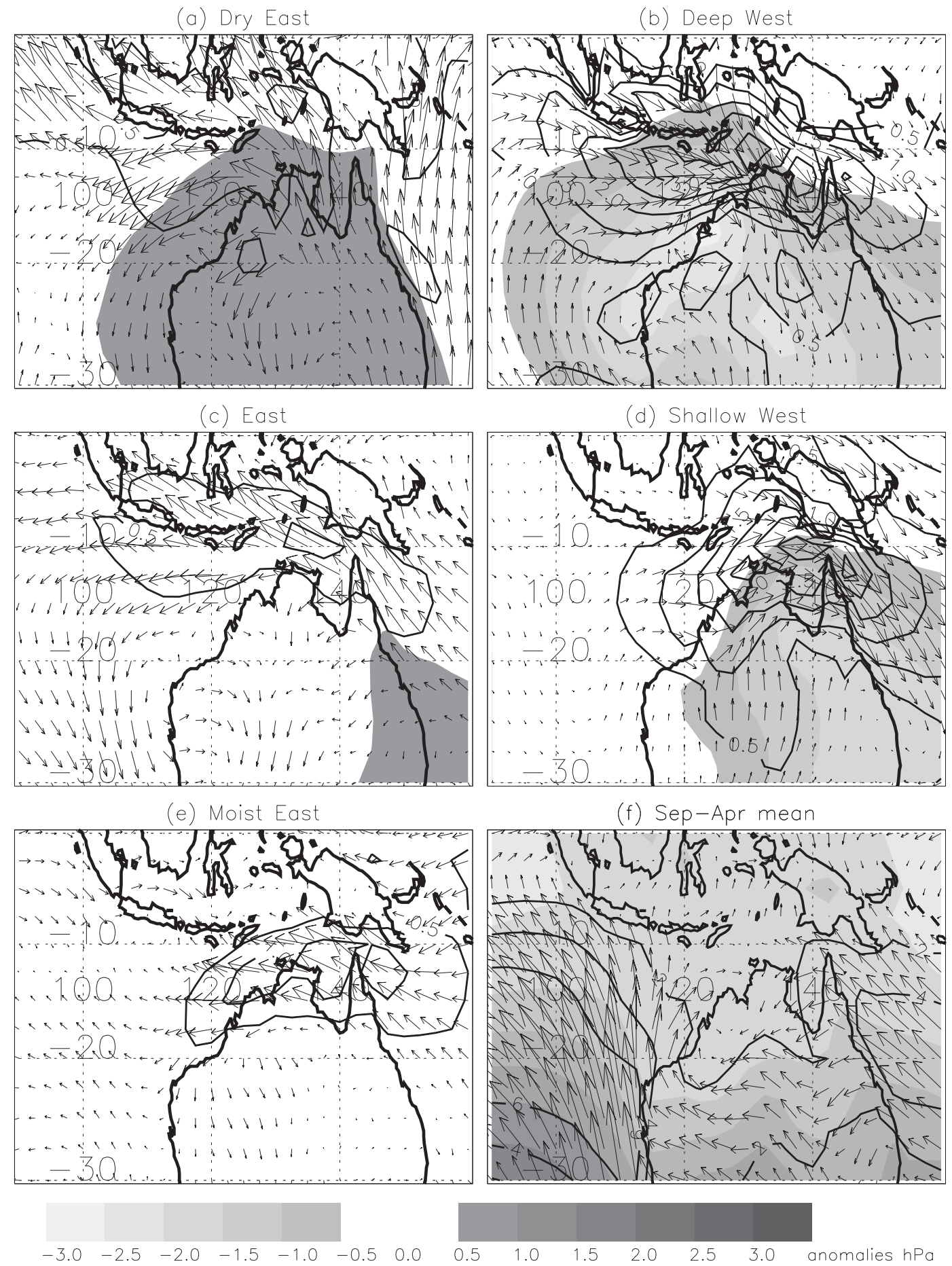

$\begin{array}{lllllll}-3.0 & -2.5 & -2.0 & -1.5 & -1.0 & -0.5 & 0.0\end{array}$

FIG. 7. (a)-(e) Mean sea level pressure and 10-m wind anomalies associated with the five wet season regimes at Darwin: MSLP anomalies every $0.5 \mathrm{hPa}$, wind anomalies every $0.5 \mathrm{~m} \mathrm{~s}^{-1}$. Also shown are (f) September-April mean 10-m wind (contours) every $2 \mathrm{~m} \mathrm{~s}^{-1}$ and MSLP (shaded) every $2 \mathrm{hPa}$ from $1008 \mathrm{hPa}$.

anomalies exist over the Coral Sea with convergence in this region. The wind anomalies over Darwin are southwesterly during the shallow west regime with southerly wind anomalies over central Australia. The pattern is consistent with an active monsoon over the Gulf of Carpentaria and the Coral Sea. The southerly component to the wind anomalies during the shallow west regime is consistent with the smaller value of precipitable water 
compared to the deep west regime, which represents the active monsoon at Darwin with air of equatorial origin.

\section{b. Radiative and rainfall patterns}

The differences in the synoptic environments for the five wet season regimes should be reflected in their associated large-scale cloud and rainfall patterns. The north Australian monsoon modulates cloudiness over northern Australia, with a peak in cloud coverage during the monsoon months of December-February (Pope et al. 2008). On an intraseasonal time scale, the active monsoon is associated with large cloudy areas owing to large mesoscale convective systems (MCSs) (McBride and Frank 1999), whereas the break monsoon is associated more with isolated deep convection and propagating MCSs or squall lines (Keenan and Carbone 1992). Isolated deep convection results in larger values of outgoing longwave radiation than the widespread stratiform regions associated with monsoonal convection.

Figures 8a-e shows the OLR anomalies from the NCEP OLR dataset (Liebmann and Smith 1996) for each of the five wet season regimes. Also shown is the mean September-April OLR (Fig. 8f). The mean OLR pattern shows the lowest values of OLR located between $5^{\circ} \mathrm{N}$ and $5^{\circ} \mathrm{S}$, with values less than $220 \mathrm{~W} \mathrm{~m}^{-2}$ over New Guinea, Sumatra, and Borneo. These regions are associated with deep convection for most of the year due to orographic uplift (e.g., McAlpine et al. 1983). The large values of OLR observed over continental Australia greater than $280 \mathrm{~W} \mathrm{~m}^{-2}$ indicate suppressed convection, consistent with the dominance of the trade wind flow (Fig. 7f). The region of OLR less than $260 \mathrm{~W} \mathrm{~m}^{-2}$ over northern Australia is indicative of the wet season.

The deep west regime (Fig. 8b) is associated with the largest and most widespread negative OLR anomalies over the entire region. This is consistent with the association of this regime with the active monsoon over the Australian region. The shallow west regime (Fig. 8d), by comparison, shows a smaller region of negative OLR anomalies over the eastern Top End and much of north Queensland. OLR anomalies for the shallow west regime are consistent with MSLP and 10-m anomalies, which indicate that the shallow west regime is associated with a monsoon farther to the east than for the deep west regime (Fig. 7). Of the three easterly regimes, only the moist east (ME) regime (Fig. 8e) is associated with negative OLR anomalies, located over the western Top End and Timor Sea. The presence of negative OLR anomalies associated with a moist zonal easterly environment is consistent with break monsoon conditions.

The east and dry east regimes (Figs. $8 \mathrm{c}$ and $8 \mathrm{a}$, respectively) are associated with widespread positive OLR anomalies consistent with suppressed convection. The dry east regime has smaller and less widespread positive OLR anomalies than the east regime even though it is associated with stronger southerly wind anomalies and drier conditions over Darwin. This is likely due to the fact that the OLR anomalies have the seasonal cycle removed.

To examine the larger-scale precipitation patterns associated with each of the five wet season regimes, Fig. 9 shows the rainfall from the GPCP version 2 rainfall dataset (Adler et al. 2003). The rainfall for each of the regimes (Figs. 9a-e) is shown as a percentage of the seasonal mean rainfall rate (September-April). The seasonal mean rainfall rate $\left(\mathrm{mm} \mathrm{day}^{-1}\right)$ is also shown (Fig. 9f). The mean seasonal rainfall rate from September to April (Fig. 9f) exhibits a north-south gradient with maximum rainfall rates of $70 \mathrm{~mm} \mathrm{day}^{-1}$ observed over Borneo and New Guinea. The areas of maximum rainfall rates correspond to regions where the OLR is less than $220 \mathrm{~W} \mathrm{~m}^{-2}$ (Fig. 8). These regions have significant topography, which aids in the production of deep convection via orographic uplift. Lower rainfall rates over the Maritime Continent are found over the oceans. The largest rainfall rates over continental Australia are found over the northwest coastal areas where the sea breeze initiates deep convection, especially during break monsoon periods (Keenan and Carbone 1992).

The dry east regime (Fig. 9a) makes the lowest contribution to the seasonal mean rainfall rate-less than $2.5 \%$ over most of continental Australia. The low rainfall rate for the dry east regimes is consistent with the dry features of the trace (Fig. 2a) and, hence, low values of precipitable water (Fig. 3a) that accompany strong southerly wind anomalies (Fig. 5a).

The deep west regime accounts for the largest fraction of the mean seasonal rainfall rate over much of continental Australia and surrounding oceans poleward of $5^{\circ} \mathrm{S}$ (Fig. 9b). The largest contribution to rainfall rate is over northwestern Australia, coincident with the position of the cyclonic wind anomalies (Fig. 7b). The region of the largest season rainfall rate contribution for the deep west regime also corresponds to the region of minimum OLR anomalies (Fig. 8b).

The east regime (Fig. 9c) contributes more to the total seasonal mean rainfall rate than the dry east regime, with the $2.5 \%$ contour covering only northern Australia, the Timor Sea, and parts of the Gulf of Carpentaria. The differences in rainfall rate distribution between the east and dry east regimes are consistent with differences in the large-scale wind flow anomalies and, by implication, the moisture advection.

The shallow west regime (Fig. 9d) makes a smaller contribution to the mean seasonal rainfall rate than the deep west regime and is concentrated particularly on the eastern half of continental Australia, coincident with 
(a) Dry East

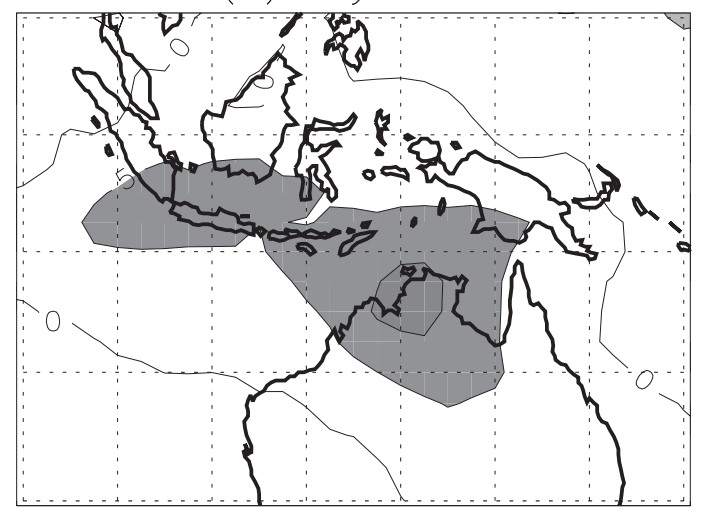

(c) East

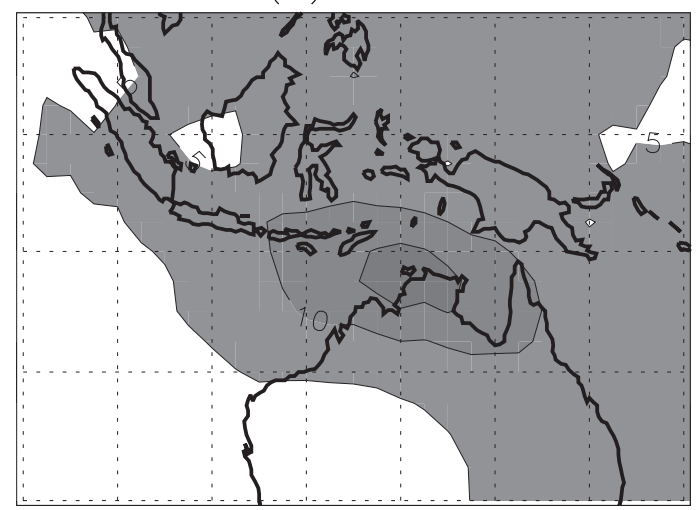

e) Moist East

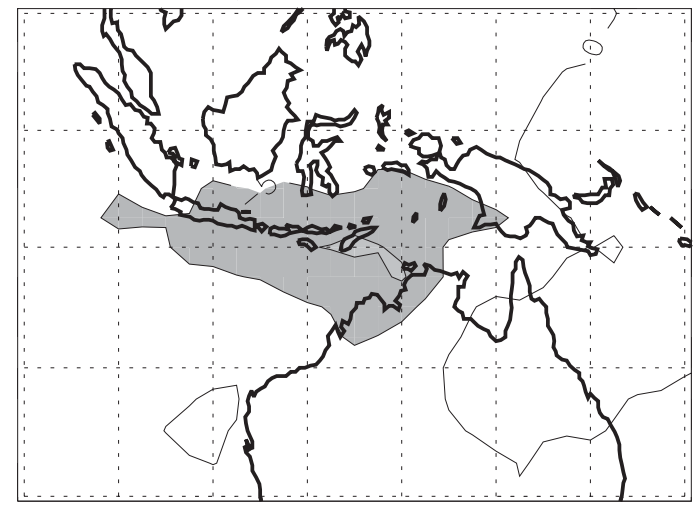

(b) Deep West

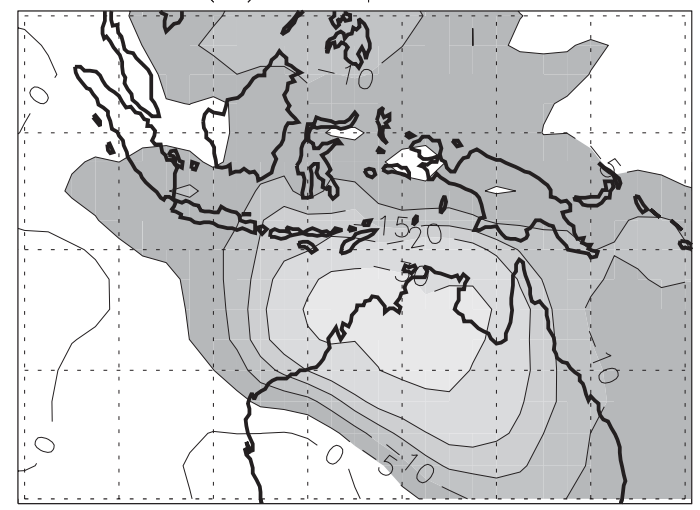

(d) Shallow West

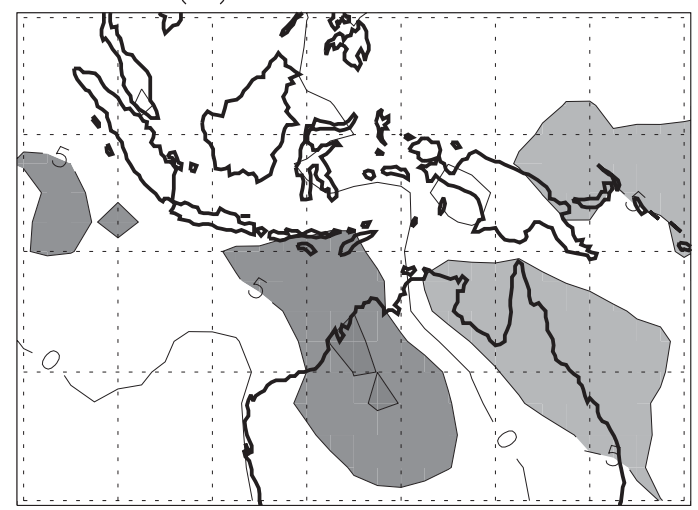

(f) Sep-Apr mean

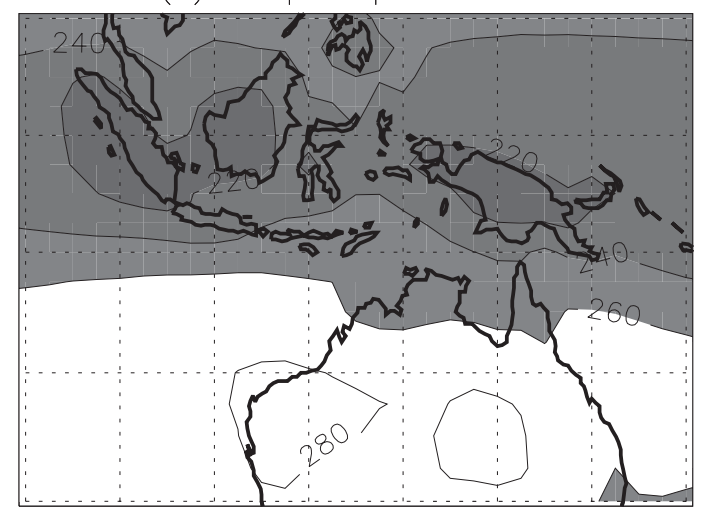

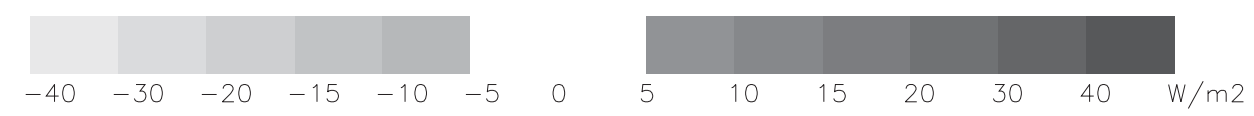

FIG. 8. (a)-(e) OLR anomalies $\left(\mathrm{W} \mathrm{m}^{-2}\right.$ ) associated with each of the wet season regimes. Anomalies have had the seasonal cycle removed. Anomalies are contoured at $5 \mathrm{~W} \mathrm{~m}^{-2}$ intervals; -5 to $+5 \mathrm{~W} \mathrm{~m}^{-2}$ unshaded. Also shown is (f) the September-April mean OLR (contoured every $20 \mathrm{~W} \mathrm{~m}^{-2}$; values below $260 \mathrm{~W} \mathrm{~m}^{-2}$ shaded). 
(a) Dry East

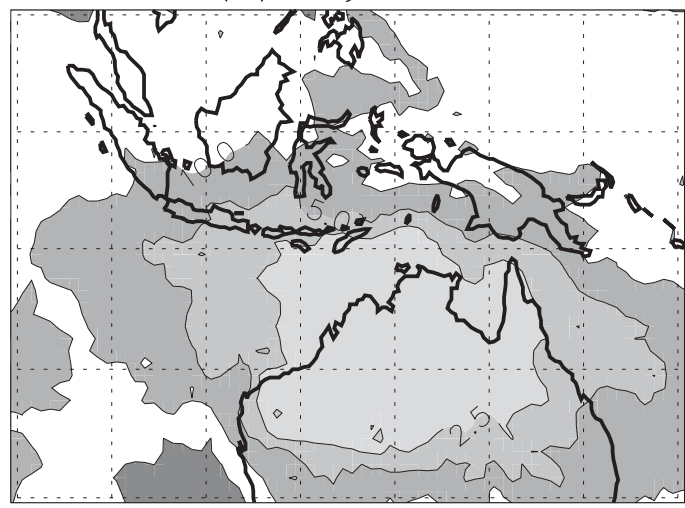

(c) East

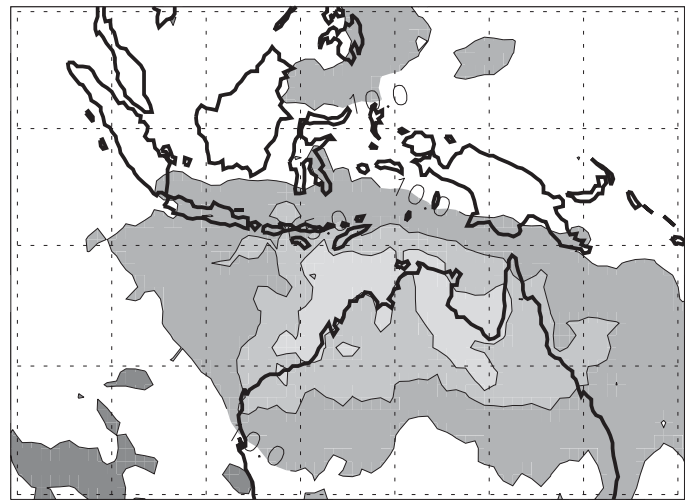

(e) Moist East

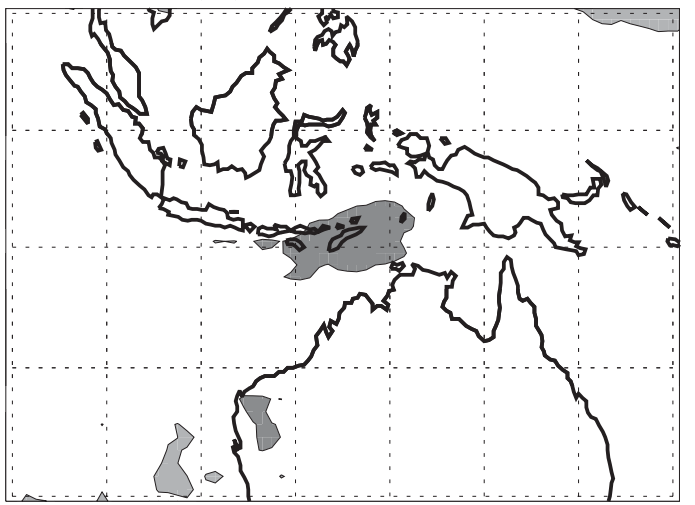

(b) Deep West

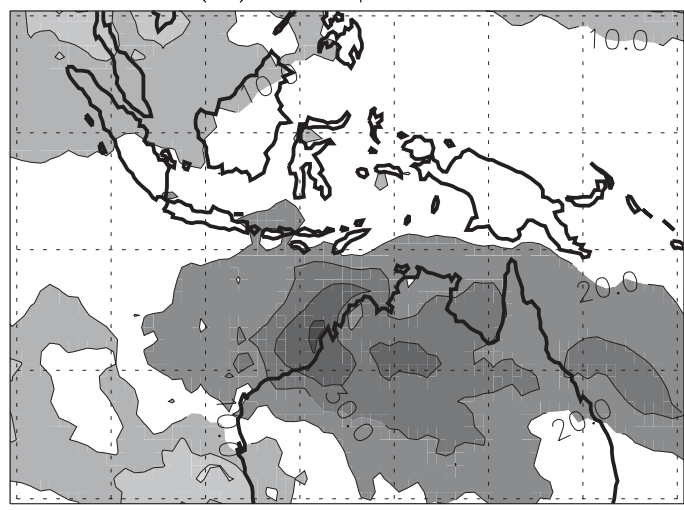

(d) Shallow West

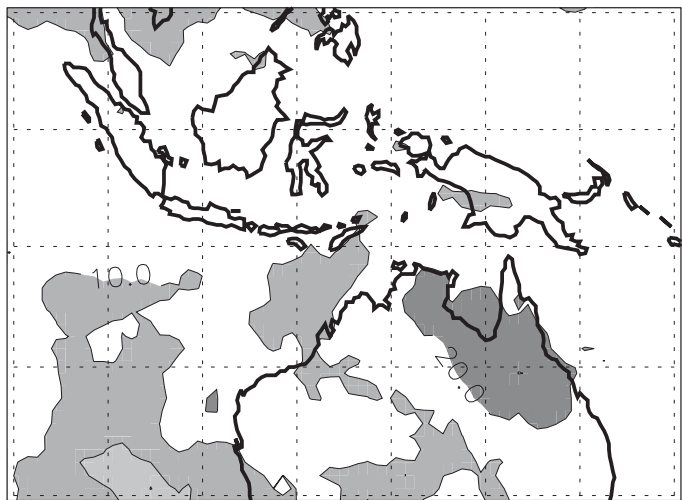

(f) Sep-Apr mean $(\mathrm{mm} / \mathrm{d})$

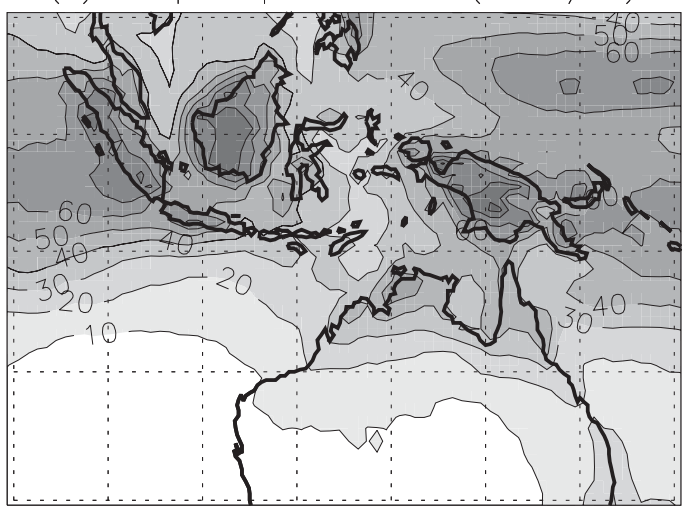

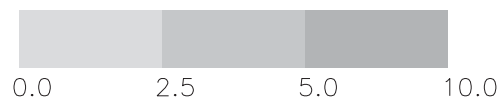

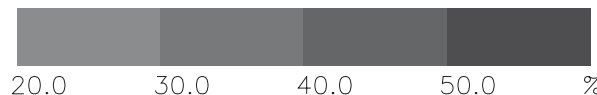

FIG. 9. (a)-(e) Rainfall contribution from each of the wet season regimes as a percentage contribution of the mean season rainfall rate. Contours are $2.5 \%, 5 \%, 10 \%, 20 \%, 30 \%, 40 \%$, and $50 \%$. Also shown is the mean season rainfall rate $\left(\mathrm{mm} \mathrm{day}^{-1}\right)$, contours at $10 \mathrm{~mm}^{-1 a y}{ }^{-1}$ intervals.

the region of associated negative OLR anomalies (Fig. 8d). While the circulation anomalies (Fig. 7d) suggest a monsoon environment over eastern Australia, the OLR anomalies and rainfall rate contributions suggest a weaker monsoon circulation than that associated with the deep west regime.

The moist east regime contributes the most to the mean seasonal rainfall rate over the entire study area, 


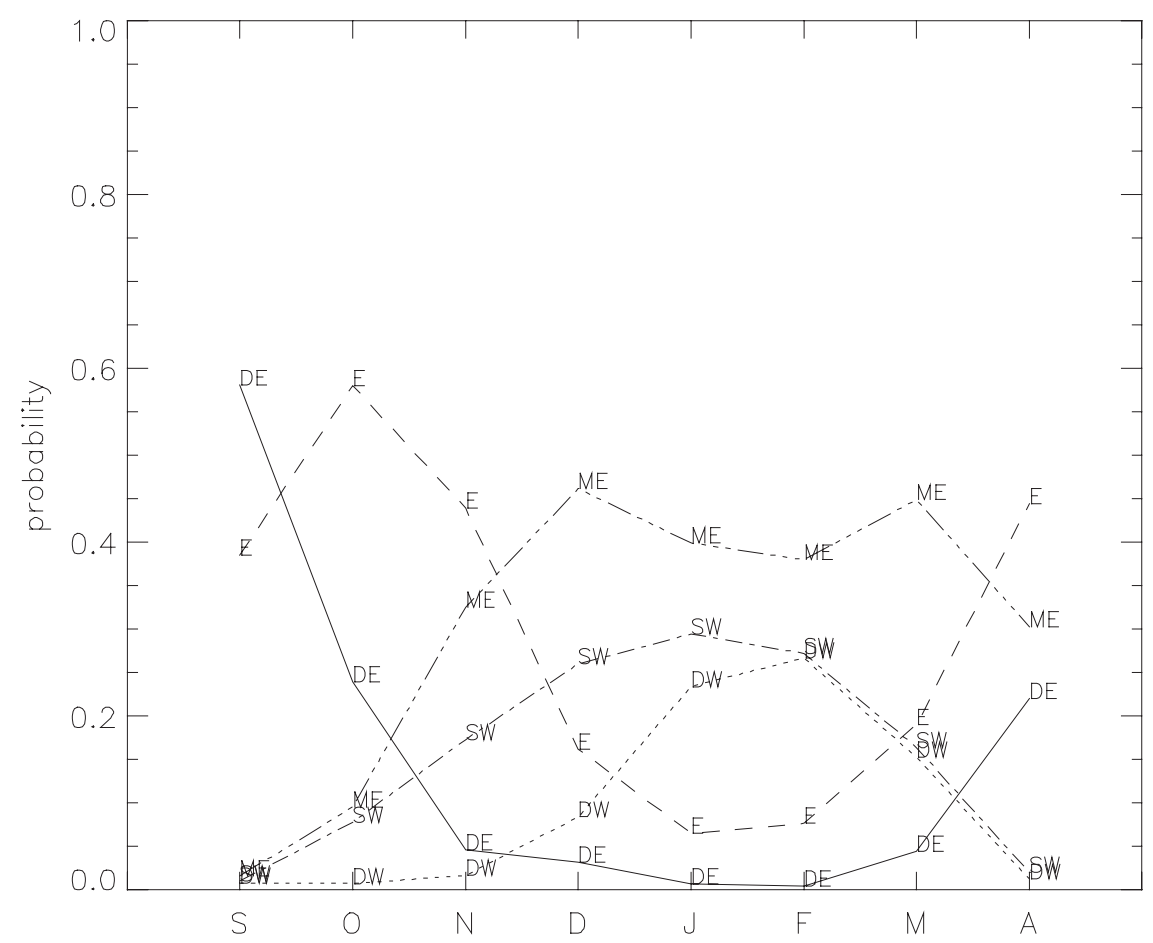

FIG. 10. Probability of observing each of the five regimes of the Darwin wet season for a given month for the period from September to April. The regimes are as in Fig. 3.

making its largest contribution over Timor and eastern Java, coincident with the region of negative OLR anomalies (Fig. 8e).

\section{c. Seasonal cycle}

The seasonal cycle of the NAM and its affect on weather and rainfall over Darwin is well documented (Nicholls et al. 1982; D96; McBride 1998). In this section, the relationship of the wet season regimes to the seasonal cycle of the NAM is examined in order to establish whether or not the regimes correspond to seasonal changes in the large-scale circulation. The frequency of occurrence of each of the five wet season regimes is shown in Fig. 10.

The dry east (DE) regime occurs on approximately $60 \%$ of days during September and $25 \%$ of days during October and April, but on less than $1 \%$ for all days during January and February. The DE regime is associated with strong surges in the south to southeasterly winds out of the eastern flank of high pressure systems over southern Australia (Fig. 7a). In the early and late part of the season, the DE regime is therefore associated with the trade wind regime. With the southward migration of the subtropical ridge during the months from November to March, this regime is associated with unusually high pressures over southern Australia.

The east (E) regime shows a similar seasonal cycle to that of the DE regime, but with smaller amplitude. The
E regime has its largest frequency of occurrence during October, November, and April and is second only to the DE regime in September. The frequency of occurrence of this regime falls below $10 \%$ during January and February. The $\mathrm{E}$ regime may best be related to the so-called buildup environment. During September and October, the heat low strengthens over the Pilbara Plateau and the trade winds begin to weaken over northern Australia (not shown). Moisture is advected at low levels over Darwin, resulting in increased values of convective available potential energy (Pope et al. 2008). The increase in low-level moisture is reflected in a strong decline in the frequency of occurrence of the DE regime from October onward, while the $\mathrm{E}$ regime persists as the dominant regime at Darwin until December.

The moist east (ME) regime is strongly the dominant regime over Darwin during the months from December to March. D96 showed that during the months NovemberApril, winds over Darwin alternate between deep westerly (active monsoon) and deep southeasterly (break monsoon). Break monsoon conditions prevail for approximately $50 \%$ of all observed days during the monsoon season, defined as the number of days between the first and last onset of DLM westerly winds with easterly winds above $300 \mathrm{hPa}$ (D96). The proportion of days during November-April during which break period days are observed approximately corresponds to the 


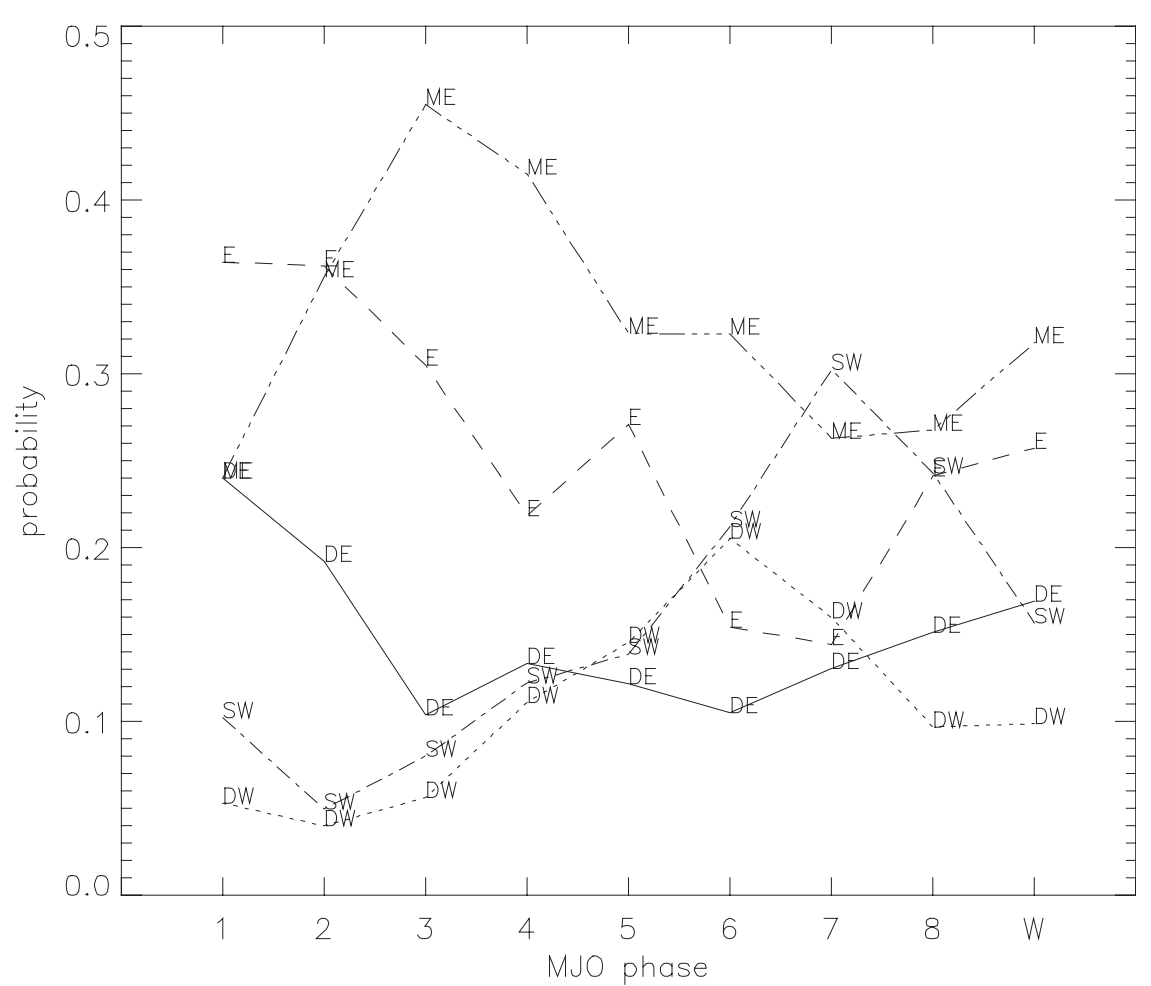

FIG. 11. Frequency of occurrence of Darwin wet season regime vs state of the Madden-Julian oscillation as measured by the real-time MJO index of Wheeler and Hendon (2004). The regimes are as in Fig. 3.

frequency of occurrence of the ME regime at Darwin during November-April. The ME regime can therefore be associated with break monsoon conditions.

The shallow west (SW) regime increases rapidly in significance from about $1 \%$ frequency of occurrence during September to about $15 \%$ in November and approximately $30 \%$ during December-February, falling off to just a few percent in April. The westerly wind profile associates this regime with the monsoon in general, but the moisture profile (Fig. 3c) and synoptic environment (Fig. 7d) suggest that some of the days falling into this regime may be associated with the so-called suppressed monsoon (May et al. 2008). Further evidence for this is discussed in section 4 .

The deep west deep west (DW) regime peaks during the months from December to March, traditionally associated with the active monsoon at Darwin (D96) at a frequency of occurrence of about $20 \%$. The cases where the deep west monsoon is observed during the period September-November are discussed in section 4.

\section{d. Intraseasonal variability}

The role of the MJO in the NAM is well documented (Hendon and Liebmann 1990; Wheeler and Hendon 2004). Wheeler and Hendon (2004) developed a real- time MJO index based on principle component analysis of 850- and 200-hPa wind fields and OLR. The real-time MJO index consists of eight phases, each of which is associated with the geographical location of the active MJO and, by implication, the suppressed MJO. Wheeler and Hendon (2004) found that, when the real-time index had sufficiently large amplitude (a value of at least one), the MJO was associated with the onset of the monsoon at Darwin. Figure 11 shows the frequency of occurrence of the five monsoon regimes at Darwin within each of the eight phases of the MJO, with cases where the amplitude of the index is less than one included as a separate class labeled $\mathrm{W}$ for weak.

The DE regime varies between about $10 \%$ and $25 \%$ of all days for each phase of the MJO, peaking during the suppressed phases (1-2) and when the MJO signal is weak. The MJO provides the strongest modulation of synoptic conditions over northern Australia during the months from December to February. Hence, the relatively weak modulation of the DE regime by the MJO is explained by the fact that this regime peaks in frequency of occurrence outside of the months where the MJO is significant for modulating the synoptic environment over northern Australia. The E regime is the most frequently observed regime at Darwin during phases 1 and 
8 of the MJO and reaches a minimum during phases 6 and 7. Phase 1 is associated with large positive OLR anomalies over Darwin (Wheeler and Hendon 2004), indicative of suppressed convection. This is consistent with the relatively low values of precipitable water associated with this regime (Fig. 3).

The ME regime is the most frequently observed during phases 2-6 and 8 of the MJO, varying from about $25 \%$ to a maximum of about $40 \%$ during phases 3 and 4 . Phases 3 and 4 represent a shift from small positive OLR anomalies to small negative OLR anomalies (Wheeler and Hendon 2004), indicating an increase in convective activity over Darwin. The ME regime is a convectively active regime at Darwin (Figs. 5 and 8) and is favored whenever atmospheric conditions are sufficiently moist for deep convection.

The DW and SW regimes increase in frequency of occurrence during the phases of the MJO associated most with monsoon onset at Darwin (Wheeler and Hendon 2004). The frequency of occurrence of the SW regime peaks during phase 7 , one phase later than the DW regime. This is consistent with the synoptic environments shown in Fig. 7, where the SW regime is associated with a trough to the east of Darwin, whereas the DW regime is associated with a low southwest of Darwin. During phase 7 of the MJO, the maximum in negative OLR anomalies is near the date line, whereas for phase 6 activity is centered near $140^{\circ} \mathrm{E}$ but also over the Top End (Wheeler and Hendon 2004). The modulation of the DW regime with the MJO is weaker than that for the SW regime; even at its peak it is never the most frequently observed regime. The onset of the monsoon is correlated with the phase of the MJO (Wheeler and Hendon 2004); however, Fig. 11 shows the total occurrence of each regime, not the correlation of the onset of a regime and the MJO. It is also clear (e.g., Hung and Yanai 2004) that the MJO is not the only factor in the onset of the monsoon. Further, some $25 \%$ of the SW regime has a wind profile matching that of an active monsoon at Darwin (not shown) such that the potential number of active monsoon regimes during phase 6 of the MJO may be monsoonal, exceeding the frequency of occurrence of the ME regime.

\section{Discussion}

The aim of the present study is to define the state of the wet season at Darwin together with a definition of the active monsoon objectively using both wind and temperature information from radiosonde data. Results of cluster analysis of 49 seasons (September-April) of 2300 UTC radiosonde data from Darwin demonstrate that a technique defining the state of the monsoon at a point location using both wind and thermodynamic information is potentially more useful than a wind-only definition in being able to diagnose the state of the atmosphere at a point and its relationship to rainfall occurrence and the larger-scale atmospheric forcing. In particular, differences in the moisture as measured by the dewpoint profile or precipitable water reflects differences in the large-scale circulation. Differences in the large-scale circulation then affect the large-scale cloud patterns as inferred from OLR and the rainfall rates.

The dry east regime can be identified with the trade wind regime at Darwin. It is most frequently observed during September-October and April, is associated with dry and convectively inactive southerly wind anomalies. The east regime is largely associated with the transition or buildup season between the trade wind regime and the onset of the monsoon, being observed early and late in the wet season. Although the wind anomalies are similar over Darwin for the east and dry east regimes, the large-scale wind field shows that there is greater moisture advection over Darwin during the east regime. The dry east and east regimes occur on a small number of occasions (less than $3 \%$ and $10 \%$, respectively) during January and February when the MJO is suppressed or weak over Darwin.

The moist east regime is associated with the wet season and break monsoon periods, being the most observed regime from December to March. It represents the default state of the atmosphere, being weakly modulated by the MJO and having weak wind and OLR anomalies. The wind anomalies show a weak trough over the Coral and Solomon Seas, and a weak cyclonic circulation near $5^{\circ} \mathrm{S}, 110^{\circ} \mathrm{E}$ associated with OLR and rainfall anomalies. The moist east regime peaks during phases 2-4 of the MJO, consistent with the results of Wheeler and Hendon (2004).

The deep west regime is associated with the active monsoon at Darwin as evidenced by the radiosonde data, seasonal cycle, and phase of the MJO. Model reanalyses show that changes in the wind and moisture field at Darwin are accompanied by a change in the large-scale circulation over the Top End of Australia and, hence, are related to the onset of the monsoon there. The shallow west regime is identified as corresponding to an active monsoon over the eastern half of Australia and into the Coral Sea, although some 25\% of these events have a wind profile that matches the monsoon at Darwin. The remaining $75 \%$ of days have a shallow westerly wind (below $1 \mathrm{~km}$ ) at Darwin. The identification of these two regimes with the active monsoon is confirmed by the phase of the MJO, when the occurrence of the shallow west regime occurs one phase later than the deep west regime, consistent with the eastward propagation of the MJO. 
TABLE 1. A comparison between wet season and monsoon season statistics for Darwin for different studies. The deep west regime corresponds to a monsoon definition, the moist east regime to a wet season onset definition.

\begin{tabular}{|c|c|c|c|c|c|}
\hline & $\begin{array}{l}\text { Mean onset } \\
\text { (Julian day) }\end{array}$ & $\begin{array}{l}\text { Mean retreat } \\
\text { (Julian day) }\end{array}$ & $\begin{array}{l}\text { Number of } \\
\text { active days }\end{array}$ & $\begin{array}{l}\text { Season length } \\
\text { (Julian days) }\end{array}$ & $\begin{array}{c}\text { Heavy rainfall } \\
\text { events }(N)\end{array}$ \\
\hline D96 & $362 / 363$ & 72 & 39 & 75.5 & 21 \\
\hline Nicholls (1984) & 339 & - & 23 & 87 & - \\
\hline Hendon and Liebmann (1990) & 359 & - & - & - & - \\
\hline Murakami and Matsumoto (1994) & 328 & - & - & - & - \\
\hline Cook and Heerdegen (2001) & 286 & 107 & - & 186 & - \\
\hline Zeng and Lu (2004) & 341 & 96 & - & 121 & - \\
\hline Janowiak and Xie (2003) & 297 & - & - & - & - \\
\hline Lo et al. (2007) & 297 & - & - & - & - \\
\hline Smith et al. (2008) & 341 & 71 & - & 96 & - \\
\hline Deep west & $353 / 354$ & $73 / 74$ & 23 & 87 & - \\
\hline Moist east & 289 & 110 & - & 188 & - \\
\hline
\end{tabular}

To examine further the relationship between the regimes and other definitions of the wet season and monsoon season, Table 1 shows the statistics of onset and retreat days for monsoon and wet season, season length, and number of active monsoon days. Onset and retreat days are shown as days of the year. The onset date is defined as the first day where the deep west regime is observed at Darwin, with retreat as the last date on which the regime is observed for the season. The season length is the number of days between onset and retreat. The number of active days is the number of days the deep west regime is observed. Also shown is the number of heavy rain active days for D96 (21 days), defined as 24-h rainfall totals of at least $15 \mathrm{~mm}$ for four or more stations used in that study.

The date of onset of the deep west regime excludes September and October events, which are spurious identifications. Mean deep west onset occurs about one week before monsoon onset, as defined by D96 and Hendon and Liebmann (1990). Removal of the November deep west onset dates improves the match between the two studies, but at the expense of missing genuine early onsets. D96 defines monsoon onset as deep westerly winds for a period of at least two days. Such a requirement could potentially improve the definition developed here. This can be seen in Fig. 6 for the 2005/06 wet season, when the D96 definition matches the first extended occurrence of the deep west regime on 10 January. The mean number of deep west days is almost half of the number of monsoon days as defined by D96, but matches closely the number of monsoon days with significant rainfall. Hence, the deep west regime is more closely identified with the active monsoon owing to the inclusion of moisture information from radiosonde data.

The moist east regime is offered here as a proxy for the onset of the wet season at Darwin because the onset of this regime is associated with the beginning of rainfall at Darwin (Fig. 6). The onset of the moist east regime precedes most of the wet season definitions. As the heat low develops over northwestern Australia, low-level westerly flow advects moist air over the Top End of Australia, increasing the rainfall potential. The use of cluster analysis to define a wet season regime, as has been done here, therefore has the potential to be used in a predictive fashion. Work to consolidate this hypothesis is beyond the scope of this study and is left for further research.

\section{Summary}

Cluster analysis using the $K$-means algorithm to analyze 49 seasons (September-April) of 2300 UTC Darwin radiosonde wind and thermodynamic information produces five objectively derived regimes of the Darwin wet season. These five regimes correspond to the trade wind environment (dry east), a transition environment between the trade winds and monsoon season (east), break monsoon conditions (moist east), the active monsoon at Darwin (deep west), and a mixed inactive and break monsoon regime at Darwin (shallow west). The monsoon regime at Darwin represents differences in the large-scale circulation; a conclusion validated by reanalysis fields, OLR, and rainfall datasets. The inclusion of thermodynamic information in a diagnosis of the state of the atmosphere at a point improves the relationship between the monsoon environment and convective rainfall by capturing important variations in airmass trajectory. Given this strong relationship of the wet season regimes with the larger-scale state of the atmosphere, they may prove useful as a tool in diagnosing the state of the atmosphere. The regimes are already being used to study variability in tropical ice clouds (A. Protat et al. 2009, personal communication) and rainfall characteristics (M. Pope et al. 2009, unpublished manuscript). The regimes may also be used to evaluate model performance under different synoptic regimes and study 
changes in the monsoon circulation resulting from anthropogenic global warming.

\section{REFERENCES}

Adler, R. F., and Coauthors, 2003: The Version-2 Global Precipitation Climatology Project (GPCP) Monthly Precipitation Analysis (1979-present). J. Hydrometeor., 4, 1147-1167.

Afifi, A., V. A. Clark, and S. May, 2004: Computer-Aided Multivariate Analysis. Chapman and Hall/CRC, 489 pp.

Arnott, J. M., J. L. Evans, and F. Chiaromonte, 2004: Characterization of extratropical transition using cluster analysis. Mon. Wea. Rev., 132, 2916-2937.

Cook, G. D., and R. G. Heerdegen, 2001: Spatial variation in the duration of the rainy season in monsoonal Australia. Int. J. Climatol., 21, 1723-1732.

Davidson, N., J. McBride, and B. McAvaney, 1983: The onset of the Australian monsoon during winter MONEX: Synoptic aspects. Mon. Wea. Rev., 111, 496-516.

Drosdowsky, W., 1996: Variability of the Australian summer monsoon at Darwin: 1957-1992. J. Climate, 9, 85-96.

Fein, J. S., and P. L. Stephens, 1987: Monsoons. Wiley, 632 pp.

Gong, X., and M. B. Richman, 1995: On the application of cluster analysis to growing season precipitation data in North America east of the Rockies. J. Climate, 8, 897-931.

Hendon, H. H., and B. Liebmann, 1990: A composite study of onset of the Australian summer monsoon. J. Atmos. Sci., 47, 2227-2240.

Hung, C.-W., and M. Yanai, 2004: Factors contributing to the onset of the Australian summer monsoon. Quart. J. Roy. Meteor. Soc., 130, 739-758.

Jackson, I. J., 1986: Relationships between rainfall days, mean daily intensity and monthly rainfall in the tropics. J. Climatol., 6 , 117-134.

— 1988: Daily rainfall over northern Australia: Deviations from the world pattern. J. Climatol., 8, 463-476.

Jakob, C., and G. Tselioudis, 2003: Objective identification of cloud regimes in the tropical Western Pacific. Geophys. Res. Lett., 30, 2082, doi:10.1029/2003GL018367.

Janowiak, J. E., and P. Xie, 2003: A global-scale examination of monsoon-related precipitation. J. Climate, 16, 4121-4133.

Keenan, T. D., and R. E. Carbone, 1992: A preliminary morphology of precipitation systems in tropical northern Australia Quart. J. Roy. Meteor. Soc., 118, 283-326.

Liebmann, B., and C. A. Smith, 1996: Description of a complete (interpolated) outgoing longwave radiation dataset. Bull. Amer. Meteor. Soc., 77, 1275-1277.

Lo, F., M. C. Wheeler, H. Meinke, and A. Donald, 2007: Probabilistic forecasts of the onset of the north Australian wet season. Mon. Wea. Rev., 135, 3506-3520.
Marteau, R., V. Moron, and N. Philippon, 2009: Spatial coherence of monsoon onset over western and central Sahel (1950-2000). J. Climate, 22, 1313-1324.

May, P. T., J. H. Mather, G. Vaughan, C. Jakob, G. M. McFarquhar, K. N. Bower, and G. G. Mace, 2008: The Tropical Warm Pool International Cloud Experiment. Bull. Amer. Meteor. Soc., 89, 629-645.

McAlpine, J. R., G. Keig, and R. Falls, 1983: Climate of Papua New Guinea, Canberra. Commonwealth Scientific and Industrial Research Organization in association with Australian National University Press, 200 pp.

McBride, J. L., 1998: Indonesia, Papua New Guinea, and tropical Australia. Meteorology of the Southern Hemisphere, Meteor. Monogr., No. 49, Amer. Meteor. Soc., 89-98.

— , and W. M. Frank, 1999: Relationships between stability and monsoon convection. J. Atmos. Sci., 56, 24-36.

Murakami, T., and J. Matsumoto, 1994: Summer monsoon over the Asian continent and western North Pacific. J. Meteor. Soc. Japan, 72, 719-745.

Nicholls, N., 1984: A system for predicting the onset of the north Australian wet-season. J. Climatol., 4, 425-435.

_ J. L. McBride, and R. J. Ormerod, 1982: On predicting the onset of the Australian wet season at Darwin. Mon. Wea. Rev., 110, 14-17.

Pope, M., C. Jakob, and M. Reeder, 2008: Convective systems of the north Australian monsoon. J. Climate, 21, 5091-5112.

- — , and —, 2009: Objective classification of tropical mesoscale convective systems. J. Climate, 22, 5797-5808.

Ramage, C., 1971: Monsoon Meteorology. International Geophysics Series, Vol. 15, Academic Press, 256 pp.

Rossow, W. B., G. Tselioudis, A. Polak, and C. Jakob, 2005: Tropical climate described as a distribution of weather states indicated by distinct mesoscale cloud property mixtures. Geophys. Res. Lett., 32, L21812, doi:10.1029/2005GL024584.

Smith, I. N., L. Wilson, and R. Suppiah, 2008: Characteristics of the northern Australian rainy season. J. Climate, 21, 4298-4311.

Troup, A. J., 1961: Variations in the upper troposphere associated with the onset of the Australian summer monsoon. Ind. J. Meteor. Geophys., 12, 217-230.

Uppala, S. M., and Coauthors, 2005: The ERA-40 Re-Analysis. Quart. J. Roy. Meteor. Soc., 131, 2961-3012.

Webster, P. J., V. O. Magaña, T. N. Palmer, J. Shukla, R. A. Tomas, M. Yanai, and T. Yasunari, 1998: Monsoons: Processes, predictability and the prospects for prediction. J. Geophys. Res., 103, 14 451-14 510.

Wheeler, M., and H. H. Hendon, 2004: An all-season real-time multivariate MJO index: Development of an index for monitoring and prediction. Mon. Wea. Rev., 132, 1917-1932.

Zeng, X., and E. Lu, 2004: Globally unified monsoon and onset retreat indices. J. Climate, 17, 2241-2248. 